\title{
Academic Papers
}

\section{New brands: Near-instant loyalty}

Received (in revised form): 11th May, 2001

\section{Andrew Ehrenberg}

has been Professor of Marketing at South Bank University since 1993. He was previously 23 years at London Business School and in industry for 15 years. He has also held academic appointments at Cambridge, Columbia, Durham, London, NYU, Pittsburgh and Warwick.

\section{Gerald Goodhardt}

is Emeritus Professor, City University; Visiting Professor, Kingston University; Adjunct Professor, University of South Australia; Visiting Research Associate, South Bank University. He was formerly Sir John E. Cohen Professor of Consumer Studies, and Dean of the City University Business School. He spent 20 years in industry and commerce prior to 20 years as an academic.

\begin{abstract}
It is widely thought that loyalty to successful new brands or line extensions evolves slowly. An unexpected but striking finding therefore is that loyalty to a new brand is nearly instant in some 20 cases examined so far: the new brands' average purchase frequency at launch is already 'normal', ie at the same level as a year or two later and also as that of competitive established brands. The finding was unexpected but now makes much sense with hindsight. More empirical work is in hand.
\end{abstract}

\section{INTRODUCTION}

An exploratory analysis of 23 successful new brands or line extensions has shown an unexpected but clear finding: the new brands' purchase frequency is almost instantly normal. So are most other standard loyalty-related measures. The exception is quarter-by-quarter repeat buying which was consistently low. Hence it seems that there were some initial 'triers' of the new brand who never became loyal to it at all. But customers who did adopt the brand were loyal from the start.

Traditionally, however, it seems to have been thought that a new brand's

Andrew Ehrenberg South Bank Business School, Southwark Campus, London Road, London SE1 OAA, UK.

Tel: +44 (0)20 7815 6169; Fax: +44 (0)20 7815 6166; e-mail: ehrenba@sbu.ac.uk repeat-buying loyalty would grow slowly over time (see, for example, Franzen ${ }^{1}$ and many earlier references the authors plan to survey such professional expectations more formally). In the past, the growth of loyalty has therefore been widely modelled in terms of consumers' so-called 'depth of repeat', meaning that repeat-buying would tend to increase whether a consumer had already bought the item once, twice, three times, etc. ${ }^{2-7}$

Despite 25,000 new products a year being launched in the USA alone, ${ }^{8}$ Hardie and his colleagues, ${ }^{9}$ Wright and Sharp, ${ }^{10}$ and others have long noted how there was in fact little systematic knowledge about how loyalty to new brands develops:

'One thing is certain - there is no rule about the level of repeat-purchasing to be expected at different levels of penetration'. ${ }^{11}$

'We expect there will often be a period of instability during which consumers' preferences for the new product are evolving'. ${ }^{12}$ 


\section{The study}

This paper therefore seeks to examine how newly-launched brands performed on a variety of repeat-buying and brand-switching performance measures. The approach was explicitly exploratory, since with new brands it was not known what to look for.

Extensive empirical regularities and matching theory (the NBD-Dirichlet model) have however long been available for established brands. ${ }^{13-18}$ This provided grounded benchmarks and a conceptual basis against which to evaluate the performance of new brands.

The analysis was for newly-launched brands or line extensions which had been broadly 'successful', ie available for retail sale for at least a year or two. ${ }^{19}$ The cases were mainly for grocery products, selected for the study by Taylor Nelson Sofres (TNS), and two prescription drugs provided by Dr Philip Stern. New brand failures (or near-failures) have been outside the scope of these early analyses, since detailed in-market data for them are more sparse.

\section{Methods}

For simplicity, data suppliers were asked to use their standard quarterly analysis periods. Sometimes data for three or four such quarters from launch were available, sometimes more. The first quarter in each case was then partially discounted, since the precise timing of the launch in the quarter was unclear (hence the 'near-instant' in the title of this paper).

Listed below are the five product categories - prescription drugs, food, drink, personal and household cleaners in which there is a total of 23 new-brand or line-extension cases, as well as comparison data on almost 100 established brands as benchmarks. All but one of these cases gave the same instant-loyalty type of result. (The exception was on much the smallest sample base and not statistically significant). Nonetheless, more extensive follow-up work is now being pursued. The product categories (new brand cases) were:

— antidepressants (2)

- cereal bars (1)

— chocolate biscuits (1)

- coffee (1)

- detergents (11), mainly the then new liquid brand variants

— fruit drinks (1)

- shampoos (1)

- tea (1)

— toothpaste (4).

\section{RESULTS}

Consumers' purchasing of a given Brand $\mathrm{X}$ in an analysis period like a quarter of a year can be broken into two main factors:

- the penetration: the percentage of consumers who bought $\mathrm{X}$ at least once in the period

- the purchase rate: how often on average buyers of $\mathrm{X}$ bought in the analysis period.

The main finding is that virtually from the start, a successful new brand's average purchase rate was at or near its subsequent 'normal' levels, and equal to the rates for the established brands in the category. This also occurred for all but one of the other loyalty-related measures analysed.

In contrast, a new brand's quarterly penetration at times increased greatly, especially for a 'real winner' (as in Table 1). In many other cases the number of buyers in a quarter levelled out quite soon.

\section{An example: Prozac}

The antidepressant Prozac was very successful when it was launched in the 
Table 1: Prozac

\begin{tabular}{|c|c|c|c|c|c|c|c|c|c|}
\hline & (QI†) & II & III & IV & $\begin{array}{l}\text { rters } \\
\text { V }\end{array}$ & VI & VII & VIII & $\begin{array}{l}\text { Average } \\
\text { QII-VIII }\end{array}$ \\
\hline Percent prescribing & 1 & 3 & 8 & 10 & 17 & 18 & 17 & 21 & 14 \\
\hline Average prescription rate* & 1.0 & 2.3 & 2.2 & 1.7 & 1.9 & 2.9 & 2.9 & 2.3 & 2.3 \\
\hline
\end{tabular}

${ }^{*}$ Average new prescriptions a quarter per prescribing doctor †The brand launched sometime in this quarter

Table 2: New brands' quarterly purchase rates (average purchase frequencies per quarterly buyer)

\begin{tabular}{|c|c|c|c|c|c|}
\hline & \multicolumn{4}{|c|}{ Quarters } & \multirow[b]{2}{*}{$\begin{array}{l}\text { Established } \\
\text { brands* }\end{array}$} \\
\hline & (I)† & II & III & $\begin{array}{l}\text { Last } \\
\text { quarter }\end{array}$ & \\
\hline Pharmaceutical drugs (2 cases) & 1.5 & 1.9 & 2.1 & 2.5 & 2.3 \\
\hline Mixed products $\ddagger$ (6 cases) & 1.1 & 1.8 & 1.9 & 1.9 & 2.2 \\
\hline Detergents (10 cases) & 1.4 & 1.9 & 2.0 & 2.0 & 2.0 \\
\hline Toothpaste (4 cases) & 1.5 & 1.3 & 1.4 & 1.4 & 1.4 \\
\hline Average (22 cases) & 1.4 & 1.8 & 1.9 & 2.0 & 1.9 \\
\hline
\end{tabular}

†Launch quarter.

$\ddagger$ Cereal bars, chocolate biscuits, coffee, fruit drinks, shampoos, tea.

* After DJ adjustment.

early 1990s. The percentage of doctors who prescribed Prozac at least once in a given quarter rose some 20 -fold over the first two years, from a penetration of 1 per cent in Q.I (the launch quarter) in Table 1 to 21 per cent in Q.VIII two years later.

In contrast, the average number of new Prozac prescriptions written in a quarter per prescribing doctor was almost at once at a rather steady level of around 2.3 , ie after the typically mixed-up launch quarter. (It is unclear when precisely in the quarter Prozac became available to particular doctors). The somewhat higher prescription rates at 2.9 in Quarters VI and VII was not typical for the other data. Overall, Table 2 shows that repeat-buying loyalty was almost instantly at its longer-term level.

\section{The various new brand cases}

The outcome for 22 of the new brands was similar, as summarised in Table 2 for quarterly purchase rates, and in Table 3 for penetration. (One small-sample detergent case is excluded, as mentioned). For conciseness, the two tables show the first three quarters and the last one available, this result being typical also of the intermediate ones.

The observed buying rates in Table 2 were broadly steady from the first full post-launch Quarter II onwards, at about 1.9 on average. They are also close to the established brands' benchmark figures, averaging also 1.9 in the last column. This was the case for really new brands like Prozac, as well as for line extensions such as the new liquid detergents.

The leading established brands had larger market penetrations than most of the new brands, as was to be expected. They also had somewhat higher purchase rates, as a manifestation of the well-established double jeopardy (DJ) phenomenon..$^{20,21}$ But the recent adjustment did not affect the conclusion (eg the average purchase rate for the detergents cases only reduced from 2.2 to 2.0 ).

Market penetrations of the new brands also stabilised soon, as shown in Table 3, other than for the two medical 
Table 3: New brands' quarterly penetrations (percentage buying the item at least once in the quarter)

\begin{tabular}{lllll}
\hline & & Averages & \\
& I $^{\dagger}$ & II & III & $\begin{array}{l}\text { Last } \\
\text { quarter }\end{array}$ \\
\hline Pharmaceutical drugs \% & 1 & 6 & 10 & 22 \\
Mixed products \% & 2 & 4 & 4 & 4 \\
Detergents \% & 2 & 7 & 5 & 6 \\
Toothpaste \% & 0 & 1 & 2 & 8 \\
Average \% & 1 & 4 & 5 & 8 \\
\hline
\end{tabular}

†Launch quarter

blockbusters which went on increasing greatly to a penetration of 22 per cent of the population (here 'Prescribing GPs').

A possibility is that most new brands simply settle down quickly in all respects, not just in their loyalty levels.

\section{Other loyalty measures}

The average frequency with which a brand is bought by its buyers in a period such as a quarter is one measure relating to its customers' 'loyalty'. It has been widely shown for established brands that this correlates closely with other measures which relate to loyalty, such as the incidence of 100 per cent-loyal buyers, the brand's shares of category requirements, and generally the levels of period-to-period repeat buying. . $2,23^{23}$

Quarter-by-quarter repeat-buying levels were, however, consistently low for the new brand cases here. At an average of 24 per cent they are much less than the norm for established brands (about 50 per cent). Period-to-period repeat-buying measures would be especially sensitive to the occurrence of once-only triallists, who are likely with new brands. This could be checked as and when more detailed tabulations are available, by using so-called 'conditional trend analysis'. (CTA analyses the repeat buying of light and heavier buyers separately, together with interpretative theoretical norms. ${ }^{24-26}$

The suggestion is that new brands do attract an exceptional incidence of once-only triallists (perhaps for the first year or two), because, perhaps, of the brand's 'newness', its exceptional concomitant publicity and retail display. The question of such triallists' 'loyalty' does not, however, really arise since they will so far have bought the item only once. The loyalty issue here is therefore that those consumers who do become loyal do so near instantly, as the evidence so far shows, rather than building up slowly, as is traditionally supposed.

\section{Previous new-brand cases}

Instantly normal average purchase frequency had already been reported in a few isolated earlier new brand cases, ${ }^{27-29}$ but these cases were discounted as unexpected aberrations. 'The fact that the new brand looked like an existing brand so quickly is a little curious'. ${ }^{30}$ The received wisdom was that new brand loyalty had to develop slowly and the authors themselves had previously accepted this. Only now, with a range of some 20 cases virtually all giving the same instant-loyalty outcome, do the earlier isolated cases seem prophetic rather than aberrations.

Supportive evidence also comes from the Unilever/RBL/ResearchInternational Minivan test panel operation. This was a mobile grocery shop that signed up a panel of housewives who could shop there once a 
fortnight as one of their retail outlets, under experimentally controlled conditions. ${ }^{31}$ The Minivan attracted a good deal of research interest from manufacturers at the time, but was ultimately abandoned. It rather accurately predicted a new brand's real-life repeat buying but failed to predict its crucial market penetrations. That is in line with the new instant-loyalty result here.

It is also understood that commercial volume forecasting of services nowadays tend to use the well-established NBD/Dirichlet model or related results to predict the test brand's repeat buying accordingly. The more difficult to predict key to a new brand's success is its ultimate market penetration - ie the number of new customers, rather than their loyalty (which depends on the variety of marketing-mix inputs).

\section{WIDER IMPLICATIONS}

The new brand finding here has wider implication. Thus the authors have previously argued that any loyalty measure for a successful new brand must ultimately settle down to the typical norm for all brands in the product category. ${ }^{32}$ This has had powerful planning implications. ${ }^{33}$ The new instant-loyalty finding for new brands now greatly strengthens this conclusion.

More generally, the authors have argued that what matters is whether a brand enters a consumer's consideration set, ie whether it stands out, is familiar, and commands assurance, which the authors call 'salience-plus'. ${ }^{34}$ 'Instant loyalty' supports this because all that can really matter to a brand's success is to how many consumers the brand is salient in that way.

The traditional view of competition is that a brand must be differentiated: consumers are thought to need a 'reason' (functional or emotional/ image-related) for choosing brand A rather than brand $\mathrm{B}$. Brands are thought to possess different levels of 'equity', either 'strong' or 'weak'. The authors' contrary view has long been that a competitive advantage is soon copied. Competition therefore consists of matching rivals on what matters, rather than of being different. ${ }^{35,36}$ This view is now strengthened by finding that even operational loyalty measures for new brands are normal, implying that they are also not seen as different.

New brands having the same degree of loyalty as established brands also fits in with the finding that similar brands appeal to similar kinds of consumers more generally - ie that competitive brands do not segment the market. ${ }^{37}$ Attitudinally, for established brands, users of brand A look at A much as users of the competitive brand B look at B. ${ }^{38}$ It now needs to be established whether or not users of a new brand also view it in the same way.

It has also been shown that temporary price cuts for established brands, ie 'deals' or 'price promotions', appeal virtually only to past customers. ${ }^{39,40}$ Price promotions therefore do not recruit new customers for established brands. For new brands, however, the mechanism must differ, since there are no past customers. This needs to be explored further.

Received wisdom is that advertising is mostly persuasive, eg that advertising motivates the consumer to become loyal to the brand. The authors have however long been arguing that this is not so. ${ }^{41}$ They believe that the finding of instant loyalty to new brands further undermines the traditional 'persuasive' views because there is no time to 'persuade'. It supports instead the alternative perspective that advertising works as publicity.

Unsuccessful new brands have not been covered by the exploratory study here. The causes of the failure of new 
brands can however be very varied, beyond mere lack of repeat buying loyalty. This is illustrated below with six cases from the authors' earlier experience.

- Case 1: In the 1960s Beechams launched a one-shot shampoo, Leaf Shampoo, a green, hand-sized and leaf-shaped specialty paper impregnated with soap to rub on wet hair. This sold like a bomb: it seemed a very attractive idea. But it had no repeat buying as the wet paper was messy to dispose of after use, whether in a shower or the bath. This should have been spotted by pre-testing.

- Case 2: Another new product failed despite much well-designed pre-launch product research. But top management was so committed to its new venture that it did not take on board that the research had in fact already given it the thumbs down.

- Case 3: Shell launched Four Seasons in the 1960s. It was the first all-year-round multi-grade motor oil. But they ignored that having priced it low to compete with the then fast-growing DIY Castrol, filling-station managers/owners would not actively sell Four Seasons because of its lower margin, compared with the standard and more expensive Shell Oil. In addition the ink on the display posters for Four Seasons ran in the rain.

- Case 4: Tate \& Lyle launched a syrup for puddings, ignoring that there were already competitive brands in the market. Hence their new syrup did not get the effortless near-100 per cent retail distribution to which they were accustomed for their other near-monopoly sugar products.

- Case 5: Delayed after-effects are not uncommon (eg skin irritation after some weeks, or slowly rotting fabric with Persil Power), often despite extensive pre-launch testing and warnings from friendly competitors.

- Case 6: Honeymoon effects wearing off (eg an attractive flavour which cloys with extended use, probably like the new Coke a few years ago).

\section{DISCUSSION}

The research outcome of this exploratory study, that successful new brands have normal loyalty virtually from the start, seems sufficiently straightforward for companies to incorporate it into their new product thinking (planning and evaluation), and for academics to incorporate it in their relevant teaching and research.

Although largely unexpected, the finding makes sense with hindsight. Thus it is believed that experienced consumers generally know that competitive brands are similar and hence largely substitutable, which is why the brands are in fact competitive. No extensive new learning about the new brand's attributes is therefore needed: the consumer can either choose it as a normal repertoire brand, or not.

Possibilities for follow-up research now include more systematic and in-depth studies of successful new brands in other product or service categories (eg television programmes) and in other countries, including emerging markets. And also studies of unsuccessful new brands. ${ }^{42,43}$ The task of collecting suitable data is eased now that one knows better what to look for.

\section{Acknowledgements}

This paper is based on work in the R\&D Initiative, a research programme at South Bank University. The results were given in a prizewinning paper given at the Marketing Academy Conference, 2000 and recorded as such in the Journal of Marketing Management. 
The authors were assisted in this work by their colleagues Dr Rachel Kennedy, Dr Neil Barnard, John Bound, Dr Carl Watson-Gandy, Jaywant Singh and Maria Clemente, and by very helpful drafting comments from Helen Bloom and an anonymous reviewer.

The authors are indebted to TNSofres for data sets from the AGB Superpanel based on some 10,000 UK households, and to ISIS Ltd. and Dr Philip Stern for the medical prescriptions data from ISIS Ltd.

The project was funded in large part by the ESRC, ROPA Grant RO22250076.

\section{References}

1 Franzen, G. and Bouwman, M. (2001) 'The mental world of brands: Mind, memory and brand success', World Advertising Center, Oxfordshire, UK.

2 Fourt, L. A. and Woodlock, J. W. (1960) 'Early prediction of market surveys for new grocery products', Journal of Marketing, Vol. 25, pp. 31-38.

3 Baum, J. and Dennis, K. E. D. (1961) 'The estimation of the expected brand choice of a new product', 17th ESOMAR/WAPOR Conference, ESOMAR, Amsterdam.

4 Parfitt, J. H. and Collins, B. J. K. (1968) 'The use of consumer panels for brand-share prediction', Journal of Marketing Research, Vol. 5, pp. 131-146.

5 Eskin, G. (1973) 'Dynamic forecasts of new product demand using a depth of repeat model', Journal of Marketing Research, Vol. 10, pp. 115-129.

6 Kalwani, M. and Silk, A. J. (1980) 'Structure of repeat-buying for new packaged goods', Journal of Marketing Research, Vol. 17, pp. 316-342.

7 Hardie, B. G. S., Fader, P. S. and Wisniewski, M. (1998) 'An empirical comparison of new product trial forecasting models', Journal of Forecasting, Vol. 17, pp. 209-229.

8 The Economist (1998) 'Market makers', 19th March, p. 67.

9 Hardie, Fader and Wisniewski (1998) op. cit.

10 Wright, M. and Sharp, A. (1999) 'New brand effects in a Dirichlet market'. Working Paper, University of South Australia, Adelaide.

11 Parfitt and Collins (1968) op. cit.

12 Fader, P. and Hardie, B. (1999) 'Investigating the properties of the Eskin/Kalwani/Silk model of repeat buying of new products', in Hildebrandt, L., Annacker, D. and Klapper, D. (eds), 'Marketing and competition in the Information Age', Proceedings of the 28th EMAC Conference, 11-14 May, Humboldt University, Berlin.

13 Ehrenberg, A. S. C. (1959) 'The pattern of consumer purchases', Applied Statistics, pp. 26-41.

14 Ehrenberg, A. S. C. (1972, 1988) 'Repeat buying', Griffin, London. Reprinted in Journal of Empirical Generalisations in Marketing Science (2000), Vol. 5, (http://www.marketing.unisa.edu.au/MSC/ JEMS_intro.html).

15 Goodhardt, G. J., Ehrenberg, A. S. C. and Chatfield, C. (1984) 'The Dirichlet: A comprehensive model of buying behavior' Journal of the Royal Statistical
Society, Vol. 147, pp. 621-655.

16 Stern, P. (1995) 'Prescriptions for branded and generic pharmaceuticals', Journal of Brand Management, Vol. 2, No. 3, pp. 177-183.

17 Stern, P. and Ehrenberg, A. S. C. (1995) 'The market performance of pharmaceutical brands', Marketing and Research Today, November, pp. 285-292.

18 Sharp, B. M. (1999) 'Evaluating the impact of a loyalty program on brand loyalty', Doctoral Thesis, University of Adelaide, Adelaide.

19 See also Davis, E. J. (1964) 'Test marketing: An examination of sales patterns found during forty-four recent tests', The Market Research Society, Research in Marketing, London.

20 Ehrenberg, A., Goodhardt, G. J. and Barwise, T. P. (1996) 'Double jeopardy revisited', Journal of Marketing, Vol. 54, pp. 82-91.

21 Ehrenberg, A. S. C., Barnard, N., Kennedy, R. and Bloom, H. (2001) 'Brand advertising as publicity', Journal of Advertising Research, (submitted).

22 Ehrenberg (1972/1988) op. cit.

23 Ehrenberg, A. S. C., Goodhardt, G. and Uncles, M. (2001) 'Using benchmarks in understanding buyer behavior', Journal of Marketing, (submitted).

24 Goodhardt, G. J. and Ehrenberg, A. S. C. (1967) 'Conditional trend analysis a breakdown by initial purchasing level', Journal of Marketing Research, Vol. 4, pp. 155-161.

25 Morrison, D. G. (1969) 'Conditional trend analysis: A model that allows for non-users', Journal of Marketing Research, Vol. 6, pp. 342-345.

26 Ehrenberg, Goodhardt and Uncles (2000) op. cit.

27 Ehrenberg, A. S. C. and Goodhardt, G. (1968) 'Repeat-buying of a new brand', British Journal of Marketing, Vol. 2, pp. 200-205.

28 Wellan, D. M and Ehrenberg, A. S. C. (1988) 'A successful new brand: Shield', Journal of the Market Research Society, Vol. 30, pp. 35-49.

29 Wright and Sharp (1997) op. cit.

30 Ibid.

31 Charlton, P., Ehrenberg, A. S. C. and Pymont, B. (1972) 'Buyer behavior under mini-test conditions', Journal of the Market Research Society, Vol. 14, pp. 171-183.

32 Ehrenberg, A. S. C. (1991) 'New brands and the existing market', Journal of the Market Research Society, Vol. 33, pp. 285-299.

33 Ehrenberg, Goodhardt and Uncles (2001) op. cit.

34 Ehrenberg et al. (2001) op. cit.

35 Dawes, J. and Page, N. (2000) 'Drivers' of service quality', Working Paper, University of South Australia.

36 Ehrenberg et al. (2001) op. cit.

37 Kennedy, R. and Ehrenberg, A. (2000) 'Competitive brands' user-profiles hardly differ', Proceedings of the MRS Conference 2000, The Market Research Society, London.

38 Barnard, N. R. and Ehrenberg, A. S. C. (2000) 'Consumer attitudes and brand-choice', South Bank University, R\&D I Report.

39 Hammond, K., Ehrenberg, A. S. C. and Goodhardt, G. (1996) 'Market segmentation for competitive 
brands', European Journal of Marketing, Vol. 30, No. 12 , pp. 30-44.

40 Hammond, K. and Ehrenberg, A. S. C. (2001) 'The case against price-related promotions', Admap..

41 eg Ehrenberg et al. (2001) op. cit.

42 Ehrenberg, A. S. C. and Charlton, P. (1973) ' An analysis of stimulated brand choice', Journal of Advertising Research, Vol. 13, pp. 21-33.

43 Lomax, W. , Hammond, K., Clement, M. and East, R. (1996) 'New entrants in a mature market', Marketing Intelligence and Planning, Vol. 12, pp. 281-295. 